\title{
Flexner 群赤俐菌の変異に関する研究
}

\section{第 1 編 Shigella flexneri 1 の変異について}

\author{
中 村 伸 藏 \\ 東京都立衛生研究所細菌部（部長 川路利順博士）
}

[受付： 9 月 28 日 1953 年]

赤㢉菌の変晎については, 滝田 ${ }^{1)}$ が $\mathrm{V}, \mathrm{W}, \mathrm{Z}$ の保存 株, 殊に V(Lentz) ついて詳細に観察し, サルモネラ のH抗原の変異のみならず, 赤㢉菌の如く H抗原のない 細菌のO抗原の変異を明かにした。次で Boyd2) は同樣 に保存株につき, 103 型菌及び P 119 型菌の変晎を報告 し, Wheeler ${ }^{3)}$ は Boyd の業績を基として詳細に抗原分 析を行い, 群抗原を更に明確にし, 現在の赤痢菌の分類 の礎石を築いた。

免度血清を加えた培地に培侌すると, 型特異抗原を失 い, R 型の出現を促淮する事は, 肺炎球菌, 肺炎桿菌, 或はサルモネラについて古くより知られている4)5)6。

私は, 赤痢患者, 保菌者等の菌檢索に当り, 生じた赤 莉菌集落多数を詳細にしらべると，同一人の糞便を培養 した平板培地に二種以上の菌型の混在し, 或は長期連続 檢索中に他型菌に沶き代ることをしばしば経驗し，その 一部は既に報告した7889910)。Sh. sonnei に於てはI相, II 相が混在することのあるのは古くから知られていた が，其他の菌型については最近まであまり注意されてい なかつたよ らである。私は上述の実例と前記諸学者の報 告に力を得て, Flexner 群赤莉囷について, 免疫血清加 肉水ブイヨンに培食することにより，比較的容易に変晎 させ得ることを確認した。本論文は之に関する実驗と， 変異に関連ありと思われる人体からの檢出例を一括して 報告するものである。

\section{I. 人体からの檢出例}

昭和 27 年以来, Sh. flexneri $1 \mathrm{~b}$ の保菌者に時々所 謂 Sh. flexneri 3 b 12)13) を檢出し, 詳細に檢索すると, 同一平板に Sh.flexneri $1 \mathrm{~b}$ と Sh. flexneri $3 \mathrm{~b}$ の混在 を認めるのみならず, Sh. flexneri 1 b と Sh. flexneri 1 a の混在, 又は Sh. flexneri $1 \mathrm{~b}$ の保菌者に Sh. flexneri $1 \mathrm{a}$ を檢出する例を経驗したので, Sh. flexneri 1 の変異に関する実驗について述べるに先立つて之等の
諸例を列挙する。劣, 診断用吸收血清は後述のるのを使 用した。

第 1 例から第 3 例迄は同一家族の者で， 3 例共に自覚 症狀はなかつた。以下檢查月日とその成績を述べる。

第 1 例 原田某, 女, 28/III, $1 \mathrm{~b} ; 5 / \mathrm{IV}, 3 \mathrm{~b}$; ( 5 個) 9/IV ; 14/IV, 1 b ; 17/IV ; 24/IV, 1 b ; 2/V, 1 b ; 4/V, $1 \mathrm{~b} ; 9 / \mathrm{V} ; 11 / \mathrm{V} ; 15 / \mathrm{V}$; (注 : 第 1 例は初回（3 月 28 日）に Sh. flexneri $1 \mathrm{~b}$, 第 2 回 (4月 5 日) に被检集 落 5 個共に Sh. flexneri 3 b, 第 3 回 (4月 9 日) は陰 性なる事を示す。以下同樣)

第 2 例 原田某, 女, $28 / \mathrm{III}, 1 \mathrm{~b} ; 5 / \mathrm{IV} ; 9 / \mathrm{IV}, 1 \mathrm{~b}$ ： 14/IV, $3 \mathrm{~b} ; 17 / \mathrm{IV}, 1 \mathrm{~b} ; 24 / \mathrm{IV}$, (I, III. $\mathrm{S}: 4,6 \cdots$ ), $27 / \mathrm{IV}, 1 \mathrm{~b} ; 2 / \mathrm{V}, 1 \mathrm{~b} ; 4 / \mathrm{V}, 1 \mathrm{~b} ; 9 / \mathrm{V}, 1 \mathrm{~b} ; 11 / \mathrm{V} ; 15 / \mathrm{V}$ 以上の如く, 第 4 回に Sh. flexneri $3 b$ を檢出, 第 6 回 に集落44 個につき檢查したが，すべて型 I 血清に弱く凝 集し，型 III 血清に著名に装集した。よつて之を更に分 離培養し，生じた集落について檢査したところ，どの集 落も型 I 血清に弱く, 型 III 血清に著明に凝集し, 型 I 又は型III 血清だげに凝集する集落は発見出来なかつ た。毎月 1 回継代し半年を経過してもこの性狀は変らな かつた。

第 3 例, 原田某, 女, $28 / \mathrm{III}, 3 \mathrm{~b} ; 5 / \mathrm{IV} ; 9 / \mathrm{IV} ; 14 / \mathrm{IV}$, 1 b ; $17 /$ IV. ( 1 b と 3 b の混在), $24 / I V, 1$ b ; 27/IV , 1 b $2 / \mathrm{V}, 1 \mathrm{~b} ; 4 / \mathrm{V}, 1 \mathrm{~b} ; 9 / \mathrm{V} ; 11 / \mathrm{V} ; 15 / \mathrm{V}$.

次の第 4 例より第 8 例迄は，或る精神病院に発生した Sh. flexneri $1 \mathrm{~b}$ による集團赤浰の際発見されたるので ある。

NAKAMURA Nobuzo: Studies on the variation of Shigella flexneri. 1. On the variation of Shigella flexneri 1. Department of Bacteriology, Tokyo-To Laboratories for Medical Sciences. -Jap. J. of Bact., 8 (9), 933-940, 1953. 
第 4 例 蒔田某, 30 歳, 男, 昭和 27 年 1 月下旬に血 便, 軽度の発熱があつた。檢查月日と成績は次の如くで ある。 $30 / \mathrm{I}, 1 \mathrm{~b} ; 4 / \mathrm{II} ; 6 / \mathrm{II}, 1 \mathrm{~b} ; 11 / \mathrm{II}, 1 \mathrm{~b} ; 14 / \mathrm{II}$; 18/II, 1 b; 21/II, 1 b ; 25/II, 1 b; 3/III ; 6/III, 1 b; 10/III, 1 b; 13/III ; 17/III, 19/, 1 b;24/III, 1 b ( 2 個) $3 \mathrm{~b}$ ( 1 個) ,27/III, I b; 31/III, 1 b : 2/IV ; 6/IV ; 10/IV, 1 b ; 21/IV, 1 b; 24/IV; 28/IV; 6/V,1 b; $8 / \mathrm{V}, 1 \mathrm{~b}$; $12 / \mathrm{V}, 1 \mathrm{~b} ; 19 / \mathrm{V}, 1 \mathrm{~b} ; 21 / \mathrm{V}, 1 \mathrm{~b} ; 26 / \mathrm{V} ; 1 \mathrm{~b}, 29 / \mathrm{V}, 2 / \mathrm{VI}$, 以上の如く, 24/III 飞同一平板より Sh. flexneri1b の 集落 2 個と Sh. flexneri $3 \mathrm{~b}$ の集落 1 個を認めた。

第 6 例 和方某, 36 嵅, 男, 昭和 26 年 9 月 上旬保下 莉したが発熱はなかつた。昭和 27 年 2 月より昭和 28 年 8 月迄の檢便の成績は次の如くである。1/II, 1 b; 7/II, $1 \mathrm{~b} ; 11 / \mathrm{II} ; 14 / \mathrm{II} ; 18 / \mathrm{II} 17 / \mathrm{IV} ; 21 / \mathrm{IV} ; 24 / \mathrm{IV} ; 6 / \mathrm{V}$. $1 \mathrm{~b} ; 8 / \mathrm{V}, 12 / \mathrm{V} ; 1 \mathrm{~b} ; 15 / \mathrm{V} ; 19 / \mathrm{V}, 1 \mathrm{~b} ; 22 / \mathrm{V} ; 26 / \mathrm{V}$; $29 / \mathrm{V} ; 2$ /VI, 1 b, 3 b ; 9/VI; 16/VI ; 23/VI; 30/VI; $7 / \mathrm{VII} ; 14 / \mathrm{VII} ; 21 / \mathrm{VII} ; 28 / \mathrm{VII}, 1 \mathrm{a} ; 4 / \mathrm{VIII} ; 11 / \mathrm{VIII}$ 18/VIII ; 25/VIII ; 1/IX ; 8/IX ; 15/IX ; 22/IX ; 29/IX; 6/X;13/X;20/X;27/X; 17/XI, 1 b (9 個), 3b (1 個), 24/XI, 1 b; 1/XII, I b ; 8/XII ; 15/XII, 1 b (9 個) , 3 b (1 個); 22/XII, 1 b; 12/I, 1 b; 19/I, 1 b; 26/I；2/II ; 4; V; 12/V;18/V; 25/V, 1 b; 1/VI, 1 b; $8 / \mathrm{VI} ; 15 / \mathrm{VI}$ 22/VI; 29/VI ; 6/VII ; 13/VII, 1 b ; 20/VII, 1 b; 27/VII 3/VIII ; 10/VIII ; 17/VIII ; 25 /VIII, 1 b; 31/VIII; 上記の如く断続的に Sh. flexneri 1b を檢出し, 2/VI, 17/XI, 15/XII v Sh. flexneri 1 b そ Sh. flexneri 3 b を同時に檢出し,28/VIr に Sh. flexneri $1 \mathrm{a}$ を檢出した。

第 7 例 橋本某, 46 歳, 女, 健康保菌者, 昭和 27 年 3 月より昰年 7 月迄に実施した檢便の成績は次の如くで ある。 3/III, 1 b; 10/III, 1 b; 13/III； 19/III, 1 b; 24/III, 4 e ((IV: 10,11 ) 11) 27/III ; 2/IV ; 6/IV ; 10/IV 14/IV ; 17/IV, 1 b ; 21/IV ; 24/IV ; 28/IV ; 6/V, 1 b; $8 / \mathrm{V}, 1 \mathrm{~b} ; 12 / \mathrm{V} ; 15 / \mathrm{V} ; 19 / \mathrm{V}, 1 \mathrm{~b} ; 22 / \mathrm{V}, 1 \mathrm{~b} ; 26 / \mathrm{V}$; 29/V; $2 / \mathrm{VI} ; 22 / \mathrm{IX} ; 29 / \mathrm{IX}, 1 \mathrm{~b} ; 6 / \mathrm{X} ; 13 / \mathrm{X} ; 20 / \mathrm{X}$; $27 / \mathrm{X} ; 4 / \mathrm{XI} ; 11 / \mathrm{XI} ; 17 / \mathrm{XI}, 1 \mathrm{~b} ; 24 / \mathrm{XI}, 1 \mathrm{~b} ; 1 / \mathrm{XII}, 1 \mathrm{~b}$ 8/XII ; 15/XII ; 22/XII, 3 c ; 12/I, 3 c ; 19/I ; 26/I, 2/II, 1 b; 9/II, 1 b; 16/II ; 23/II, 1 b; 2/III, 1 b; 17/III, 1 b 24/III, 1 b; 30/III, 1 b; 6/IV ; 13/IV ; 20/IV, 1 b ; $27 / \mathrm{IV}, 1 \mathrm{~b} ; 4 / \mathrm{V} ; 12 / \mathrm{V} ; 18 / \mathrm{V}, 1 \mathrm{~b} ; 25 / \mathrm{V}, 1 \mathrm{~b} ; 8 / \mathrm{VI}$; 15/VI ; 22/VI ; 29/VI ; 6/VII ; 13/VII ; 20/VII ; 27/VII 上記の如く一年余り断続的に Sh. flexneri $1 \mathrm{~b}$ を証明し たが, 28/VII に Sh. flexneri 1a を, 又22/VII 及び 12/I K所謂 Sh. flexneri 3c (III. S : 6・.)12) を証明 した。
第 8 例 前田某, 女, 健康保菌者, 赤痢患者の関係者 として炤和 27 年 3 月より昭和 28 年 7 月迄に行つた檢便 の成績は次の如くである。10/III, 1 b; 17/III；19/III; 24 /III ; $28 / \mathrm{III} ; 2 / \mathrm{IV} ; 6 / \mathrm{IV} ; 10 / \mathrm{IV} ; 14 / \mathrm{IV} ; 17 / \mathrm{IV}$; $21 / \mathrm{IV}, 1 \mathrm{~b} ; 24 / \mathrm{IV}, 1 \mathrm{~b} ; 6 / \mathrm{V} ; 8 / \mathrm{V} ; 12 / \mathrm{V} ; 15 / \mathrm{V} ; 19 / \mathrm{V}$; $22 / \mathrm{V} ; 26 / \mathrm{V} ; 29 / \mathrm{V} ; 2 / \mathrm{VI} ; 9 / \mathrm{VI} ; 16 / \mathrm{VI} ; 23 / \mathrm{VI} ; 30 / \mathrm{VI}$ 7/VII ; $14 / \mathrm{VII} ; 21 / \mathrm{VII} ; 28 / \mathrm{VII} ; 4 / \mathrm{VIII} ; 11 / \mathrm{VIII}$; 18/VIII ; 25/VIII ; 1/IX; 8/IX,1 b; 22/IX ; 29/IX ; $6 / \mathrm{X} ; 13 / \mathrm{X} ; 20 / \mathrm{X} ; 27 / \mathrm{X} ; 4 / \mathrm{XI}, 1 \mathrm{~b} ; 11 / \mathrm{XI} ; 17 / \mathrm{XI}$; $24 / \mathrm{XI} ; 1 / \mathrm{XII} ; 8 / \mathrm{XII}, 1 \mathrm{~b} ; 15 / \mathrm{XII}, 1 \mathrm{~b} ; 23 / \mathrm{XII} ; 12 / \mathrm{I}$, $1 \mathrm{~b} ; 19$ /I $; 26 / \mathrm{I} ; 2 / \mathrm{II}, 1$ b; $9 / \mathrm{II} ; 16 / \mathrm{II} ; 9 / \mathrm{III} ; 17 / \mathrm{III}$; 23/III, 1 b; 30/III ; 6/IV ; 13/IV ; 20/IV, 1 b ; 27/IV, $1 \mathrm{a} ; 4 / \mathrm{V} ; 13 / \mathrm{V} ; 18 / \mathrm{V}, 1 \mathrm{a} ; 25 / \mathrm{V}, 1 \mathrm{a} ; 1 / \mathrm{VI}, 1 \mathrm{a}$; 8/VI; 15/VI; 22/VI; 29/VI; 6/VII; 13/VII, 1 a; 20/VII; 27/VII；以上の如く, 1 カ月乃至 4 カ月の間 隔で Sh. flexneri $1 \mathrm{~b}$ を檢出したが，27/IV に Sh. flexneri $1 \mathrm{a}$ を檢出し, 以後の陽性例はすべて Sh. flexneri $1 \mathrm{a}$ で Sh. flexneri $1 \mathrm{~b}$ は檢出されなかつた。 第 9 例 石沢某, 48 嵗, 男, 飲食店從業員で, 赤浰の 既往はない。飲食業者の保菌者檢索の際に発見されたも ので, 初回に SS 寒天平板上に Sh. flexneri 1 a と Sh flexneri $1 \mathrm{~b}$ の混在を認めたので, 更に 43 個の集落を 檢査し, 35 個の Sh. flexneri $1 \mathrm{~b}$ と 8 個の Sh. flexneri 1 a を檢出した。第 2 回, 第 3 回は除性であつた。

第 10 例 荻野某，女，赤刘患者の関係者として檢便 を行い, 初回 (3/VII)) 集落4 個の中, 3 個出 Sh. flexneri $1 \mathrm{~b}$ であつたが，他の 1 個は I 型血清のみなら ず型 III 血清汇も㠜集を認めた。第 2 回 (26/VII) は Sh. flexneri 1b のみを檢出したが，第 3 回 (31/VII) は Sh. flexneri $1 \mathrm{~b}$ と Sh. flexneri $3 \mathrm{~b}$ が混在してい た。4/VIII, 14/VIII は共に陰性であつた。

\section{II. 変異の実驗}

1. 実驗方法

1）診断用吸收血清の作りかた。

型 I 血清 Sh. flexneri 1 a-Ew. 8 抗血清を Sh. flexneri var.Y-Ew.13 倸び Sh. flexneri var. X-Ew.12 で吸收した。

型 III 血清 Sh. flexneri 3 a-Ew. 14 抗血清を Sh. flexneri 1 b-Ew. 9 , Sh. flexneri 4 b-Ew. 18 及び Sh. flexneri var. X-Ew. 12 で吸收した。

S血清 Madsen ${ }^{14)}$ は Sh. flexneri 1 b 亿特巽な抗 原について述へ，之を $\mathrm{S}$ 抗原と称した。 $\mathrm{S}$ 血清の作り方 は, Sh. flexneri 1 b-Ew. 9 抗血清を Sh. flexneri 1 a-E w. 8 , Sh. flexneri 3 a-Ew. 14 及び Sh. flexneri 4 b-E 
第 1 表 $S$ 血清 の作 リ方

\begin{tabular}{|c|c|c|c|c|c|c|c|c|c|}
\hline \multirow{2}{*}{ 血 清 } & & \multicolumn{2}{|c|}{ 蒔 } & \multicolumn{3}{|l|}{ 田 } & \multicolumn{3}{|c|}{ Ewing 標 準 株 } \\
\hline & $\sqrt{2}$ & $1 \mathrm{a}$ & $1 \mathrm{~b}$ & $3 \mathrm{~b}$ & $Y(\leftarrow-1 a)$ & $\mathrm{Y}(\leftarrow 3 \mathrm{~b})$ & 1 a & $3 a$ & $4 \mathrm{~b}$ \\
\hline \multirow[t]{5}{*}{ Sh. flex. 1 b (Ew.9) } & - & 640 & 5120 & 2560 & 80 & 160 & 1280 & 2560 & 2560 \\
\hline & Sh. flex.1a (Ew.8) & 0 & 1280 & 2560 & 0 & 0 & 0 & 2560 & 1280 \\
\hline & Sh. flex.3a (Ew.14) & 640 & 640 & 160 & 40 & 0 & 640 & 0 & 40 \\
\hline & Sh. flex.4b (Ew.18) & 160 & 640 & 160 & C & 40 & 320 & 160 & 0 \\
\hline & $1 a+3 a+4 b$ & 0 & 320 & 160 & 0 & 0 & 0 & 0 & 0 \\
\hline
\end{tabular}

註凝集價 40 倍未満は 0 とする。

w. 18 で吸收した。その結果は第 1 表の如く, Sh. flexn eri 1 b 飞 320 倍, Sh. flexneri 3bに 160 倍迄㠜集す る。

洋 3 血清 当所分離滰出株（Sh. flexneri 2 a) 抗血 清を Sh. flexneri2b-Ew. 40Pr, Sh. flexneri var. X-Ew. 12 及び Sh. flneri 1 b-E-W 9 で吸收した。この血清沈 Sh. flexneri 2 a 及び Sh. flexneri 4 a 亿著明に凝集し， Sh. flexneri1 b 及び Sh. flexneri 1 a に凝集しない。 群 4 血清 Sh. flexneri 2 a-Ew. 10 抗血清を Sh. flexneri 2 b-Ew. 40 PR 及び Sh. flexneri var. X-Ew: 12 で吸收した。この血清は Sh. flexneri 1 a, Sh. flexn eri $1 \mathrm{~b}$, Sh. flexneri $2 \mathrm{a}$ によく凝集し, Sh. flexneri 4 a に凝集しない。

群 6 血清 Sh. flexneri 4 b-Ew 18 抗血清を Sh. flexneri 4 e (荒井) 及び Sh. flexneri var. Y-Ew. 13 で吸收した。Sh. flexneril b-Ew. 9 抗血清を Sh. flexneri 1 a-Ew. 8 及び Sh. flexneri var. Y-Ew.13 で吸收 しても得られるが，この場合は所謂 S 抗体が含まれるこ とになる。

2）培地の作りかた。

抗血清を肉水ブイヨンでそれぞれ 100 倍, 200 倍, 500 倍, 1000 倍に稀橎し, 小試驗管に分注し, $52^{\circ} \mathrm{C}, 2$ 時間, 1 日 1 回, 3 日間減菌して無菌なる事を確めた上 使用に供した。

3）変巽株の檢出方法

この培地に供試菌を接種し，1日， $37^{\circ} \mathrm{C}$ に培養し， 生じた集落についてスライド凝集反應を行つた。2日目 よりは $30^{\circ} \mathrm{C}$ 乃至 $25^{\circ} \mathrm{C}$ の温度に放置し, 日を追つて平

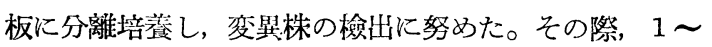
2 日に 1 回試驗管を振蕰して管底の凝集菌を平等な菌液 とした。

4）供試菌は次の諸株（Sh. flexneri 1b）を用いた。 䓓田株 （前記第 4 例より分離）
鈴木株 （前記第 5 例より分離）

荻野株（前記第10例上り分離）

原田株（前記第 2 例より分離)

夏目株（東京都立駉込病院上り分與）

昭和 15 号株（当所保存）

Ew.-9 株 (國立予防衛生研究所より分與)

5）培地に加える抗血清

Sh. flexneri 1 a 秋元株（当所分離）凝集價 1:5120

Sh. flexneri 1 b 小山株（当所分離）凝集價 $1: 5120$

Sh. flexneri $3 \mathrm{a}$ 山田株（当所分離）凝集價 $1: 10240$

Sh. flexneri 3 b 莊田株（当所分離）凝笨價 1: 5120

2. 実驗成績

1）蕂田原怢を Sh. flexneri 1 a 抗血清加肉水ブイヨ ンに培養し，之より平板に分離培養して生じた集落につ き菌型を決定すると，第 2 表の如く，培羡 1 日では抗血 清 500 倍稀鄱培地及び 1000 倍稀粎培地より分離培養し

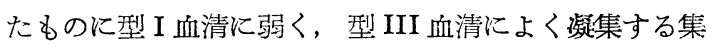
落が出現した。 4 日培養では 500 倍稀䣋培地より分離培 養したものは，9個の中， 8 個は（III. S: $4,6 \cdots$ ) 即 ち Sh. flexneri $3 \mathrm{~b}$ であつた。 8 日培荃では 200 倍稀勫 培地に於て Sh. flexneri $1 \mathrm{~b}$ の他に 5 個は型 I 血清及び 型 III 血清に同程度に㠜集した。この集落を更に平板汇 分離培養して生じた集落 20 個につきスライド㠜集反應 を行つたが，すべて型 I 血清及び型 III 血清に凝集し，一 方だけに凝集する集落は発見出来なかつた。然し，更に 累代培養を行つた結果, 型 III 血清に嚆する㠜集能は次 第に弱くなり，6 代培鋀に於ては型 III 血清には凝集せ ず, 本来の Sh. flexneri 1 b になつた。然し 500 倍, 1000 倍稀釈のものより分離培養して得られた Sh. flexneri 3 $\mathrm{b}$ は 5 カ月間継代保存するも何等抗原構造に変化を来さ なかつた。39 日培荃のものでは 100 倍稀釈及び 1000 倍 稀釈より分離培養したがすべて生兄ず， 200 倍及び 500 倍稀棌のものでは, 集落数がかなり減少し, 型 III 血清 
第 2 表

Sh. flexneri $1 \mathrm{~b}($ I.S : 4,6・・)（蕂田原株）より Sh. flexneri 3 b (III S : 4,6・・) 又は（I III S : 4,6・・) への変異

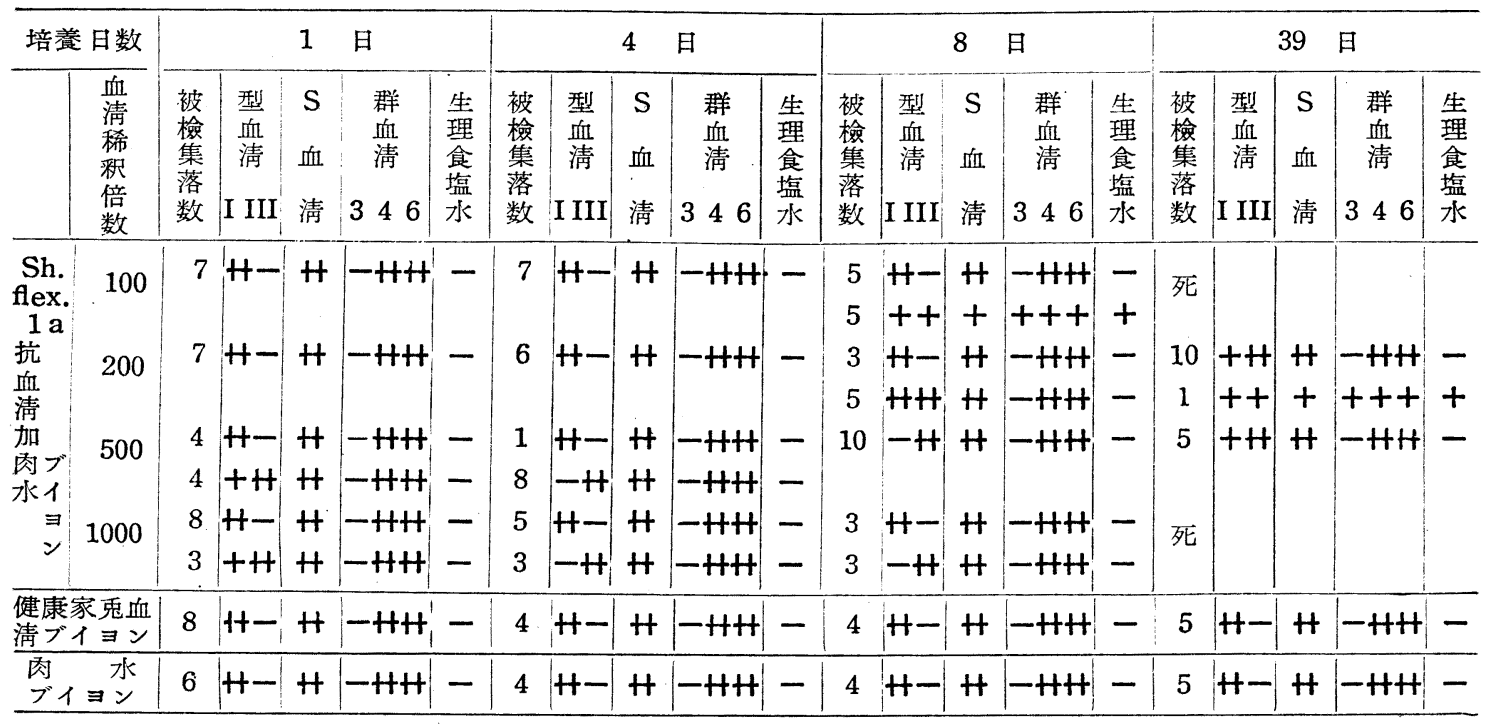

第 3 表 Sh, flexneri 1 b (I.S : 4,6・・) (蕂田原株) より Sh. flexneri 1 a (I : 4・・) への変異

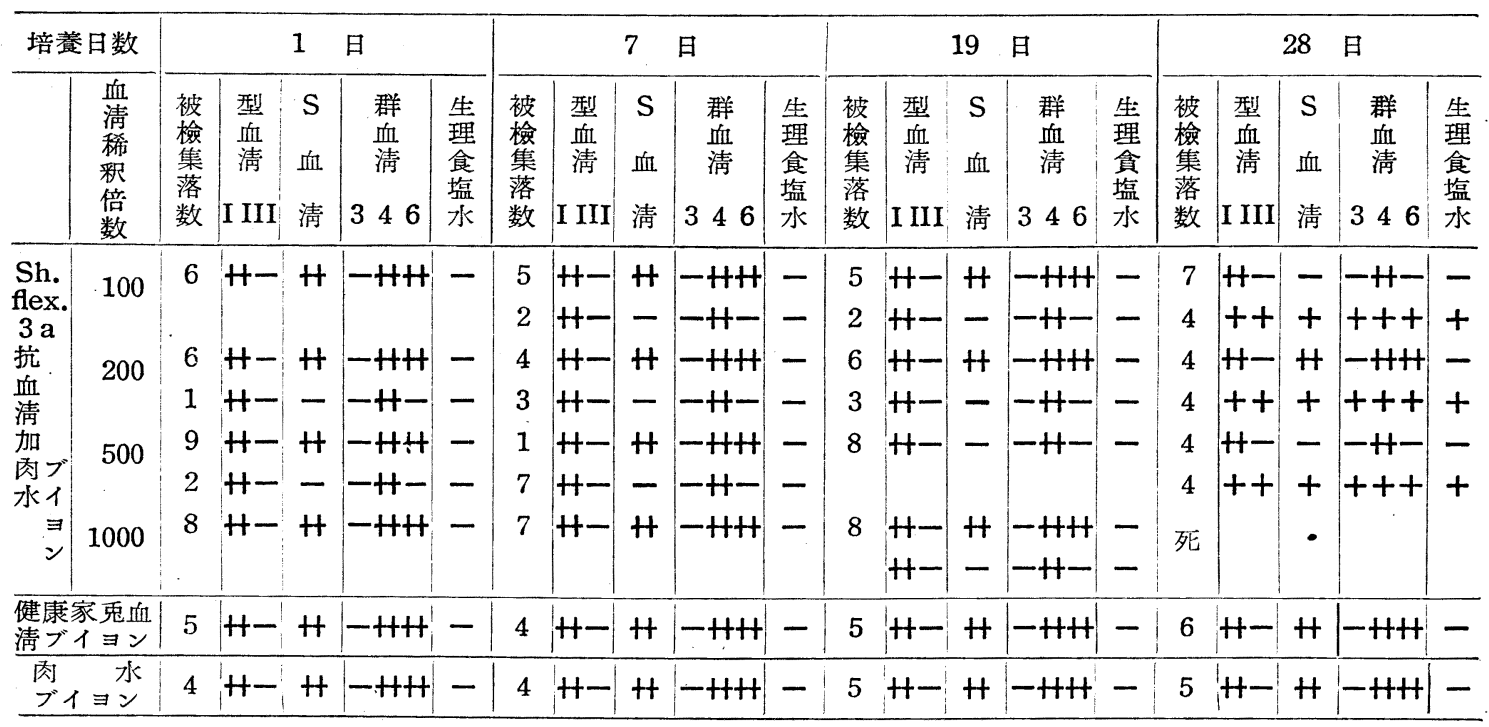

によく凝集し，型 I 血清に弱く凝集する集落を得た。之 等の集落は 40 日間保存後再び平板に分離培養したがす ベてR型となつた。

蒔田原株は Sh. flexneri $1 \mathrm{~b}$ の抗血清加肉水ブイヨン に培養したものについては，8日目よりR型が出現した だけで，37日目まで Sh. flexneri $3 \mathrm{~b}$ 其他の変異株の 出現は認められなかつた。

蒔田原株を Sh.flexneri 3a 抗血清加ブイヨンに培養 936
した結果は第 3 表の如く，1 日培養で 200 倍及び 500 倍 稀釈培地から Sh. flexneri 1 a が出現し, その際対照と して 200 倍稀䆏健康家鬼血清加ブイヨン及び肉水ブイョ ン培養のすのは変晎菌を認めなかつた。又, 莳田原株で $0.5 \mathrm{mg} / \mathrm{ml}$ の生理食塩水浮游液を作り, 前述の如く抗血 清加肉水ブイヨンを作つた時と同㧼の方法により，この 菌浮游液で抗血清加菌液を作り之を氷室に 1 日放置した ものについて同樣，平板に分離培養したものでは変異株 
第 4 表 Sh. flexneri 3 b (III.S : 1,6 : ) (蒔田変界株) より Sh. flexneri 1 b (I.S : 4,6・・) への変異

\begin{tabular}{|c|c|c|c|c|c|c|c|c|c|c|c|c|c|c|c|c|c|c|c|c|c|}
\hline \multicolumn{2}{|c|}{ 培養日数 } & \multicolumn{5}{|c|}{2} & \multicolumn{5}{|c|}{6 目 } & \multicolumn{5}{|c|}{12 日 } & \multicolumn{5}{|c|}{26 日 } \\
\hline & $\begin{array}{l}\text { 血 } \\
\text { 清 } \\
\text { 稀 } \\
\text { 釈 } \\
\text { 倍 } \\
\text { 数 }\end{array}$ & $\begin{array}{l}\text { 被 } \\
\text { 檢 } \\
\text { 集 } \\
\text { 落 } \\
\text { 数 }\end{array}$ & $\mid \begin{array}{l}\text { 型 } \\
\text { 血 } \\
\text { 声 } \\
\text { I III }\end{array}$ & $\begin{array}{l}S \\
\text { 血 } \\
\text { 清 }\end{array}$ & $\mid \begin{array}{c}\text { 群 } \\
\text { 血 } \\
\text { 淸 } \\
346\end{array}$ & $\begin{array}{l}\text { 生 } \\
\text { 㻎 } \\
\text { 食 } \\
\text { 塩 } \\
\text { 水 }\end{array}$ & $\begin{array}{l}\text { 被 } \\
\text { 檢 } \\
\text { 蕉 } \\
\text { 落 } \\
\text { 数 }\end{array}$ & \begin{tabular}{|l} 
型 \\
血 \\
淸 \\
I III
\end{tabular} & $\begin{array}{l}\mathrm{S} \\
\text { 血 } \\
\text { 淸 }\end{array}$ & $\mid \begin{array}{ccc}\text { 群 } \\
\text { 血 } \\
3 \\
3\end{array}$ & $\begin{array}{l}\text { 生 } \\
\text { 理 } \\
\text { 食 } \\
\text { 塩 } \\
\text { 水 }\end{array}$ & $\begin{array}{l}\text { 被 } \\
\text { 檢 } \\
\text { 集 } \\
\text { 落 } \\
\text { 数 }\end{array}$ & $\left|\begin{array}{c}\text { 型 } \\
\text { 血 } \\
\text { 清 } \\
\text { I III }\end{array}\right|$ & \begin{tabular}{|c}
$\mathrm{S}$ \\
血 \\
清
\end{tabular} & $\begin{array}{c}\text { 群 } \\
\text { 血 } \\
\text { 淸 } \\
346\end{array}$ & $\begin{array}{l}\text { 生 } \\
\text { 瑆 } \\
\text { 食 } \\
\text { 憩 } \\
\text { 水 }\end{array}$ & $\begin{array}{l}\text { 被 } \\
\text { 檢 } \\
\text { 集 } \\
\text { 落 } \\
\text { 数 }\end{array}$ & $\begin{array}{c}\text { 型 } \\
\text { 血 } \\
\text { 淸 } \\
\text { I III }\end{array}$ & $\begin{array}{l}\mathrm{S} \\
\text { 血 } \\
\text { 淸 }\end{array}$ & 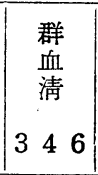 & $\begin{array}{l}\text { 理 } \\
\text { 食 } \\
\text { 塩 } \\
\text { 水 }\end{array}$ \\
\hline \multirow{5}{*}{$\begin{array}{l}\text { Sh. } \\
\text { flex. } \\
3 \text { b } \\
\text { 抗ブ } \\
\text { 血イ } \\
\text { 清 } \\
\text { 加ン }\end{array}$} & 100 & 15 & $-t+$ & $H$ & $-H+H$ & - & 9 & $-H$ & $T T$ & $-H+t$ & . & 8 & $-H$ & tt & $-+t+1$ & & & $T T$ & + & & + \\
\hline & 200 & 12 & $-H$ & $t+$ & -+++ & - & 6 & $-H$ & $H$ & $-H+H$ & - & 8 & $-H$ & $H$ & $-H+H$ & - & 全部 & ++ & + & +++ & + \\
\hline & 500 & 4 & $-t+$ & $H$ & $-H+t$ & - & 5 & $-H$ & $H$ & $-H+H$ & - & 3 & $\mathrm{H}-$ & $H$ & $-t+t+$ & - & 6 & $\mathrm{H}-$ & $H$ & $-H+H$ & - \\
\hline & 300 & 6 & ++ & + & +++ & + & 10 & ++ & + & +++ & + & 10 & ++ & + & +++ & + & 1 & ++ & + & +++ & + \\
\hline & 1000 & 13 & $-H$ & $H$ & $-H+t$ & - & 6 & $-H$ & $H$ & $-H+H$ & - & 7 & $-H$ & $t+$ & $-H+H$ & - & 5 & $-H$ & $H$ & $-H+t$ & - \\
\hline \multicolumn{2}{|c|}{$\begin{array}{l}\text { 健康家鬼血 } \\
\text { 清ブイヨン }\end{array}$} & 5 & $-H$ & $H$ & $-t+t$ & - & 4 & $-H$ & $H$ & $-H+H$ & - & 5 & $-H$ & $H$ & $-H+H$ & - & 全部 & ++ & + & +++ & + \\
\hline 7 & $\begin{array}{l}\text { 氷 } \\
\text { ヨン }\end{array}$ & 5 & $-H$ & $H$ & $-H+$ & - & 4 & $-H$ & $H$ & $-H+H$ & - & 5 & $-H$ & $H$ & $-H+H$ & - & & + & + & +++ & + \\
\hline
\end{tabular}

は出現しなかつた。

2. 蒔田変晎株 (Sh. flexneri 3 b) (III. S : 4,6・r) の変巽

第 1 表の 8 日培養の 1000 倍稀釈より生じた Sh. flexneri 3 b を Sh. flexneri 3 b 抗血清加ブイョンに培養し て変異株の出現狀況を調べた。第 4 表の如く，2 日培養 では，500 倍稀釈より平板に分離培養した集落の過半数 は R 型であつた事が特異で，其他の変異は認められなか つた。6 日培養に於ても変異株の出現は認められず, 500 倍稀粎に於ては更に R 型が增加し，90\% 以上を占 め，残りの S 型集落の中，5個についてスライド凝集反 焦を行つたが，ボ・゙て型 III 血清と群 4 及び群 6 血清に 凝集した。12 日培養に於ては，500倍稀釈のものからは 約 $80 \%$ R 型で，残りの $\mathrm{S}$ 型集落の中， 5 個について スライド凝集反應を行つたが，すべて型 III 血清には凝 集せず，型 I 血清と群 4，群 6 血清に凝集した。26 日
培養に於ては， 100 倍及び 200 倍稀釈のものからはすべ てR型，500 倍稀釈のものからはR型が $20 \%$ 位に減少 し，S型が增加し，その中の 6 個について調べたがすべ てSh. flexneri 1 b であつた。

第 2 表の 8 日培養の 500 倍稀釈のものより分﨎培養し た Sh. flexneri $3 \mathrm{~b}$ について前述の実驗を再び試みた結 果は第 5 表の如く，1 日培養の 100 倍稀䣋に於ては，集 落 9 個の中， 6 個は型 III 血清 S 血清及び群 6 血清に凝 集せず，群 3 及び群 4 血清のみに凝集した。即ち，Sh. flexneri var. Y に相当する变異株を得た。以上同じ蒔 田変晎株 (Sh. flexneri 3 b) から一方はSh. flexneri 1b えの, 他方は Sh. flexneri var. Y えの変異を認めた。

3. 蒔田変異株 (Sh. flexneri 1 a) の変異

第 3 表の 1 日培養, 500 倍稀翻より得た Sh. flexneri 1 a について Sh. flexneri 1 a 抗血清加ブイヨンに培養 した結果, 第 6 表の如く, 1 日培算の 500 倍稀釈培地よ

第 5 表 Sh. flexneri 3 b (III S : 4,6・・) (蕂田変異株) より Sh. flexneri, var. Y $(-:$ 3,4・・) への変界

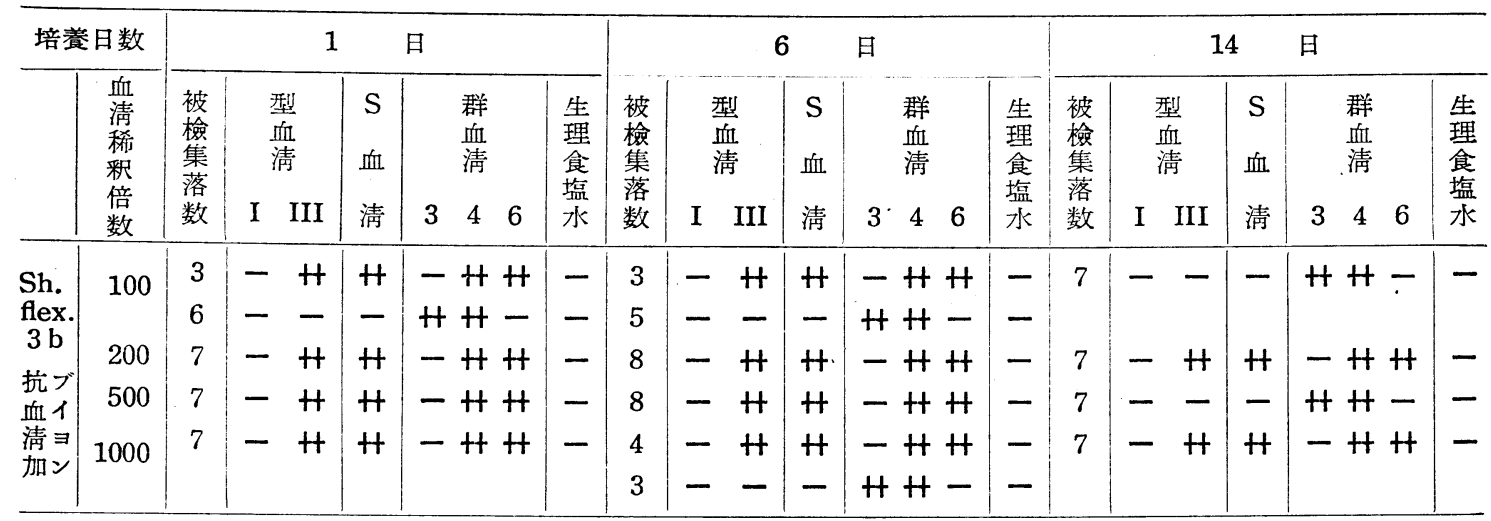


第 6 表 Sh. flexneri 1 a $(I ： 4 \cdots)$ (蕂田変異株) より Sh. flexneri var. Y (一： 3,4・・) への変異

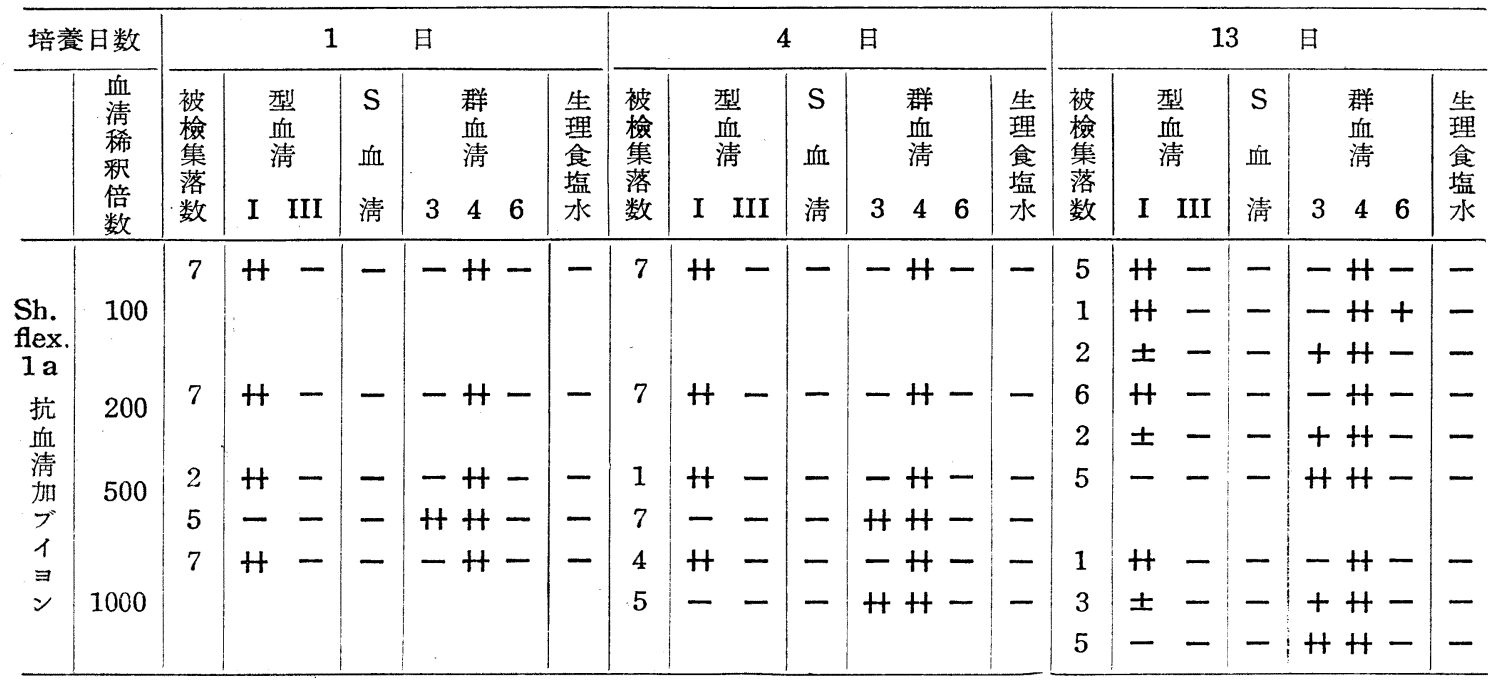

第 7 表 蒔 田株 の 交叉凝 集 反 贋 成 綪

\begin{tabular}{|c|c|c|c|c|c|c|c|c|c|c|c|c|}
\hline \multirow{2}{*}{\multicolumn{2}{|c|}{ 抗血淸 }} & \multicolumn{2}{|c|}{ 蒔 } & 田 & \multicolumn{2}{|l|}{ 株 } & \multicolumn{3}{|c|}{ Ewing 標 } & 準 & \multicolumn{2}{|c|}{ 株 } \\
\hline & & $1 \mathrm{a}$ & $1 \mathrm{~b}$ & $3 \mathrm{~b}$ & $Y(\leftarrow 1 a)$ & $Y(\leftarrow 3 b)$ & $1 a$ & $1 \mathrm{~b}$ & $3 a$ & $4 \mathrm{~b}$ & $x$ & $\mathrm{Y}$ \\
\hline \multirow{5}{*}{$\begin{array}{l}\text { 蒔 } \\
\text { 田 } \\
\text { 株 } \\
\text { 抗 } \\
\text { 血 } \\
\text { 淸 }\end{array}$} & $\mathrm{a}$ & 2560 & 5120 & 160 & 1280 & 1280 & 1280 & 2560 & 160 & 80 & 640 & 1280 \\
\hline & b & 1280 & 2560 & 2560 & 160 & $\cdot 160$ & 1280 & 5120 & 5120 & 2560 & 640 & 1280 \\
\hline & $\mathrm{b}$ & 160 & 5120 & 10240 & 1280 & 640 & 320 & 2560 & 2560 & 2560 & 640 & 1280 \\
\hline & $Y(\leftarrow 1 a)$ & 160 & 40 & 320 & 1280 & 640 & 160 & 40 & 160 & 80 & 1280 & 2560 \\
\hline & $Y(\leftarrow 3 b)$ & 1280 & 320 & 1280 & 5120 & 2560 & 1280 & 160 & 1280 & 1280 & 5120 & 5120 \\
\hline \multirow{5}{*}{$\begin{array}{c}\text { Ew } \\
\text { 標 } \\
\text { 準 } \\
\text { 株 } \\
\text { 抗 } \\
\text { 血 } \\
\text { 淸 }\end{array}$} & 1 & 1280 & 1280 & 160 & 640 & 320 & 2560 & 2560 & 160 & 160 & 1280 & 2560 \\
\hline & 1 & 640 & 5120 & 2560 & 80 & 160 & 1280 & 5120 & 2560 & 2560 & 160 & 320 \\
\hline & 3 & 160 & 5120 & 5120 & 1280 & 1280 & 160 & 2560 & 5120 & 2560 & 1280 & 1280 \\
\hline & & 320 & 2560 & 5120 & 1280 & 1280 & 160 & 1280 & 2560 & 2560 & 640 & 1280 \\
\hline & $\mathrm{Y}$ & 1280 & 1280 & 1283 & 1280 & 2560 & 640 & 640 & 2560 & 2560 & 5120 & 10240 \\
\hline
\end{tabular}

第 8 表 Sh. flexneri 1 b (蒔田原株) と Sh. flexneri 3 b (蒔田変異株) の交叉吸收試驗成綪

\begin{tabular}{|c|c|c|c|c|c|c|c|c|}
\hline \multirow{2}{*}{ 抗 } & \multirow{2}{*}{ 收 } & \multicolumn{2}{|c|}{ Ew. } & 標 & 準 & \multicolumn{2}{|l|}{ 株 } & 蒔田株 \\
\hline & & 1 a & $1 \mathrm{~b}$ & $3 \mathrm{a}$ & $4 \mathrm{~b}$ & $\mathrm{X}$ & $\mathrm{Y}$ & $3 \mathrm{~b}$ \\
\hline \multirow[t]{2}{*}{ Sh. flex. 1 b (蒔田) } & - & 1280 & 5120 & 5120 & 2560 & 640 & 1280 & 2560 \\
\hline & [Sh. flex. $3 \mathrm{~b}$ (蒔田) & 320 & 640 & 0 & 0 & 40 & 40 & 0 \\
\hline \multirow[t]{3}{*}{ Sh. flex. 3 b (蒔田) } & - & 320 & 2560 & 2560 & 2560 & 640 & 1280 & 10240 \\
\hline & Sh. flex. $1 \mathrm{~b}$ （蒔田） & 0 & 0 & 320 & 320 & 80 & 80 & 640 \\
\hline & $1 \mathrm{~b}$ (蒔田) $+4 \mathrm{~b}$ (Ew.18) & 0 & 0 & 80 & 0 & 0 & 0 & 80 \\
\hline
\end{tabular}

註：凝集價 40 倍末満はと 0 する。 
り分離培養したものでは， 7 個の集落の中， 5 個の $\mathrm{Sh}$. flexneri var. Y に相当する変曈株を得た。Sh. flexneri $1 \mathrm{~b}$, Sh. flexneri $3 \mathrm{a}$, Sh. flexneri $3 \mathrm{~b}$ 抗血清加ブイ ヨン培養のものから変異株の出現はみられなかつた。

他の 6 株について子同樣な実驗を行つたが, 分離間も ない菌株のみならず，昭和 15 号株， Ew-9 株の如き長 期保存の菌株も同㥞の变暲型式をとつた。

次に蒔田原株及びその変㬴株について交叉㠜集反鷹を 行つた結果は第 7表の如くで, 刘照として Ewing 標準 株をも用いた。この成績は型及び群血清を用いて変異株 の同定を行つた結喿と大体一致するが，Sh. flexneri1b より変基した Sh. flexneri var. Yは, Sh. flexneri var. Y.Ew. 13 と稍了荘る如き結果になつている。第 8 表の如く, 蕂品原株 (Sh. flexneri 1 b) 抗血清を蕂田変 買株（Sh. flexneri 3b) で吸收すると Sh. flexneri $1 \mathrm{a}$ 友び Sh. flexneri 1 b 江特買な抗体が残り Sh. flexneri $3 \mathrm{~b}$ には型I 抗原をもたない事がうかがわれ, 又, 蒔田 変巽株 (Sh. flexneri 3 b) 抗血清を Sh. flexneri 1 b支 び Sh. flexneri $4 \mathrm{~b}$ て吸收すると, 凝集俉は低いが Sh. flexneri 3 a 亿特罢的飞㠜集することょりこの Sh. flexneri $3 \mathrm{~b}$ 型 III 抗原のあることが知られる。

な和上記の各変界株の生物学的性狀即らブドウ糖, 孚 糖, 蔗糖, キシローゼ, マンニット，マルトーゼ，アラ ビノーゼ, ラムノーゼ, アドニット, ソルビット, ラフ イノーゼ等の分解能及びインドール反應の成續は夫及の 原菌株とほとんど変らなかつた。

\section{小括並びに考按}

Sh. flexneri 1 b は Andrewes 及び Inman ${ }^{15)}$ により 一つの subrace VZ として報告されたもので， Boyd”) はこの VZ につき言及し，VZはV (Sh. flexneri 1a) の型特異抗原を有しているが Z (Sh.flexneri 3a) の型 特巽抗原は有せず， $Z$ の性質は恐らくは $\mathrm{V}, \mathrm{X}$ 及び $\mathrm{Z}$ にもある共通抗原によるものであろうと述べている。然 るに Weil 等(16)は，VZ はV 及び Zの主抗原を有する とし, Sh. paradysenteriae I, III と記した。

Sh. flexneri 1 の变㟟は, V 型菌について滰田1)の業 績が最初であり, 之は赤痢菌の変暴の最初の報告でもあ る。1952 年, 篠川等闺は菌株保存中纪 Sh. flexneri 1 b よりSh. flexneri 1 a, 3 b, 3c に変異した事を報告した。 著者の実驗成績も氏等の報告と一致した。即ち Sh. flexneri 1 b から Sh. flexneri 1 a, Sh. flexneri 3 b えの 変異を認めた他, (I. III. S : 4, 6‥) 或は Sh. flexneri var. Y えの变暴を, 就中, 一部には可逆的な関係 を認めた。それ等の成績を一括して図示すると次の通り
となる。

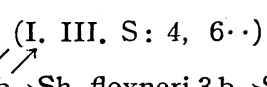

Sh. flexneri $1 \mathrm{~b} \rightarrow$ Sh. flexneri $3 \mathrm{~b} \rightarrow$ Sh. flexneri var. $Y$ (I. S : $4,6 \cdot) \leftarrow$ (III. S : 4,6・) $\quad(-: 3,4 \cdot \cdot)$ Sh. flexneri $1 \mathrm{a} \rightarrow$ Sh. flexneri var. Y $(\mathrm{I}: 4 \cdots) \quad(-: 3,4 \cdots)$

このような変暴が人体内で起るか否かは興味をひく問題 であるが，同一人から血清学的に異る赤㢉菌を檢出した 著者の自驗例から, Sh. flexneri 1b を中心に拾つてみ ると, Sh. fliexneri $1 \mathrm{~b}$ と Sh. flexneri $3 \mathrm{~b}$ が 6 例; Sh. flexneri $1 \mathrm{~b}$ と Sh. flexner 1 a が 2 例, Sh.flexneri $1 \mathrm{~b}$ と Sh. flexneri $1 \mathrm{a}$ 及び Sh. flexneri $3 \mathrm{~b}$ が 1 例 Sh. flexneri $1 \mathrm{~b}$ そ Sh. flexneri $3 \mathrm{c}$ 及び Sh. flexneri $4 \mathrm{e}$ が 1例である。その一部から分離された赤痢菌につ いては上述の如く試驗管内で変異が証明されたわけであ る。又, Sh. flexneri $1 \mathrm{~b}$ と Sh. flexneri $3 \mathrm{c}$ 及び Sh. flexneri 4 e の例については, Sh. flexneri $4 \mathrm{e}$ の檢出を 理論的に裏付けることが困難であるが，他の総ての例で は人体内に於斿る変暴が推定出来るものと思考する。

\section{結論}

赤莊菌㨿血清を加えたブイヨンに培羡することにより Sh. flexneri $1 \mathrm{~b}$ から Sh. flexneri $1 \mathrm{a}$, Sh. flaxneri $3 \mathrm{~b}$ Sh. flexneri var: Y 及び (I. III. S : 4,6・・) の抗原を 有する赤㢉菌えの变翼を証明し, この変晎によつて裏付 けられる人体内に於ける推定变暴例について述べた。

終りに終始御指導, 御鞭撻を賜つた川路博士並びに辺 野喜博士に深謝する。な扣本研究は文部省科学研究費の 援助を受けた。茲に感謝の意を表する。

\section{文献}

1) Takita, J.: A new type of antigenic variation occurring in the Flexner group of dysentery bacilli, J. Hyg., 37, 271 279, 1937

2) Boyd, J.S.K.: The antigenic structure of the mannitol-fermenting group of dysentery bacilli, J. Hyg.,38, 477 499, 1938

3) Wheeler, K. M.: Antigenic relationship of shigella paradysenteriae J. Immunol., 48 87 106, 1944

4) Stryker, L. M. : Variations in the pneumococcus inducedby growth in immune serum, J. Exp. Med., 24, 49 68, 1916

5) Julianelle, L. A.: Immunological relationships of encapsulated and capsule-free strains of Eucapsulatus pneumoniae (Friedläuder's bacillus). J. Exp. Med., 44, 683 696, 1926

6) Arkwright, J. A. and Pitt, R. M.: The effect of growing smooth and rough cultures 
in serum. J. Path. and Bact., 32, 229 246 1929

7) 中村伸藏： 駒込 B III 菌 (2b) そX, 及ど駒込 B III 菌（2a）とYとの同時檢出例について, 第 5 回日本細菌学会関東支部総会演說抄錄, 昭 和 26 年 11 月

8）中村伸藏：同一人ょり血清学的に異つれ二種類 の赤莉菌の檢出について, 日本傳染病学会雜誌 $26,1 \sim 3,1952$

9）中村伸藏：同一人上 $\eta$ 血清学的飞異る赤浰菌の 檢出とついて(続報) 口演, 第7 回日本公衆衞生 学会, 昭和 27 年 8 月

10）中村伸藏：同一人上り血淸学的飞異る赤浰菌の 檢出について（続報其の 2 ), 日本傳染病学会誌 27, 111 113, 1953

11) Fukumi H., Nakaya R., Nakayama T.:Antigenic structure of Shigella flexneri type .4, Japanese Med. Jour. 4, 37 42, 1951

12）策川至, 池村謙吾： Flexner 群赤㝝菌標準株 （学振 Weil, Ewing) の比較照合と Sh. flexneri 型並びに群血淸に就て, 新潟縣衞生試騟所研究
報告, 第 40 輯, 昭和 26 年 11 月

13) Fukumi, H., Nakaya, R. and Nakayama, T. Antigenic structure of Shigella flexneri 3 , Japanese Med. Jour. 4, 15 17, 1951

14) Madsen, S.: On the classification of the Shigella Types.Einer Munksgaard, Copenhagen, 1949

15) Wilson, G. S. \& A. A. Miles:Topley and Wilson's Principles of Bacteriology and Immunity, 3 rd. edition. 1945, p. 689 より引用

16) Weil, A. J., Black, J. and Forsetta, K.:The serological types of Shigella paradysenteriae (Flexner). II. Types with dual primary anti gens - Practice of typing discussion. J. Im munol., 49, 341 351,1944

17）篠川至, 小泉衡平, 池村謙吾 : Sh. flexneri $1 \mathrm{~b}$ の変異に就て, 日本細菌学襍誌, $7,370,1952$

18）策川至, 小泉衡平, 池村謙吾: Flexner 赤浰菌 の分類とその相変異に就て，(口演）第 7 回日本 公釆衞生学会, 昭和 27 年 8 月

\title{
正誤表 第 8 巻第 8 号
}

頁 行

表紙著者名

P. 819 著者名

P. 813

䒱 題
䛊

原之俊

Middlebrook-Dudos
正

原 元俊

"

Middlebrook-Dubos

第 8 栐 7 第

P. 651

\author{
松井清治・富川栄一論文
}

右行 培地組成の次に Final pH 7.0 を入れる。

以上当方の手落でしたので著者に拕詑びして訂正いた

します

編集委員 